\title{
PERILAKU HIPERAKTIF PESERTA DIDIK DAN PENANGANANNYA (STUDI KASUS DI SDN INPRES BUMI BAHARI)
}

\author{
Nurheda ${ }^{1)}$ Rusdin $^{2)}$ Titin $^{2)}$ \\ e-mail: nurheda123@gmail.com \\ ${ }^{1}$ Mahasiswa Program Studi PGMI FTIK Institut Agama Islam Negeri Palu \\ ${ }^{2}$ Dosen Fakultas Tarbiyah Ilmu Keguruan Institut Agama Islam Negeri Palu
}

\begin{abstract}
The aims to research on students' hyperactive behavior and its handling (case study in SDN Inpres Bumi Bahari) which is discussed into sub-problems, namely how is the behavior of hyperactive learners at SDN Inpres Bumi Bahari? What efforts have been made in handling hyperactive behavior of students at SDN Inpres Bumi Bahari ?. This study uses a qualitative approach, data collection techniques through observation, interviews and documentation. The results of this study indicate that the behavior of students who are hyperactive they are always difficult when invited to concentrate when the learning process, attention is easily distracted especially when he feels bored. At the time in the class he often ran to and fro and often in and out of class for no apparent reason. They most like to disturb their friends in class. My students' various behaviors of students really train the patience of the teacher during the learning process. Efforts made in handling the behavior of hyperactive learners of a teacher are applying the rules slowly to students, helping students in learning, using positive reinforcement. Give the same treatment as other friends, warn classmates not to be antipathy towards him, put a hyperactive position in the front seat of students, do not give penalties that are too heavy, given the hyperactive punishment of students will feel more responsible for what he did. Motivating to be more enthusiastic in the learning process. The results of the study are expected that teachers must be more creative in managing the learning process, so that students in SDN Inpres Bumi Bahari can concentrate well during the learning process.
\end{abstract}

Keywords : hyperactive, Behaviour, Handling

\section{PENDAHULUAN}

Generasi baru harus dididik menggunakan akal dan juga generasi muda harus dididik secara terbuka kepada orang lain dan menaruh sifat menyendiri dan tanpa berlebihan menonjolkan dirinya. Sebagaimana yang tercantum dalam $(\mathrm{Q}$. S. Az-Zumar [39]: 9):

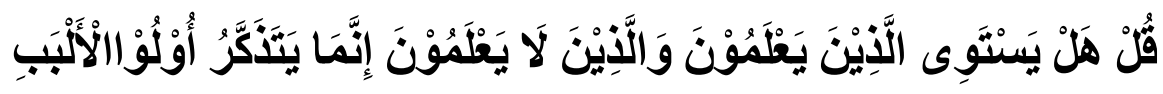


Terjemahan:

Katakanlah, apakah sama orang-orang yang mengetahui dengan orangorang yang tidak mengetahui. Sesungguhnya orang yang berakallah yang dapat menerima pelajaran. (Q. S Az-Zumar [39]: 9: ). ${ }^{1}$

Anak perlu dididik karena anak dilahirkan tidak berdaya, anak manusia lahir tidak dilengkapi insting yang sempurnah untuk dapat menyesuaikan diri dalam menghadapi lingkungan, anak perlu masa belajar yang panjang sebagai pesiapan untuk dapat secara tepat berhubungan dengan lingkungan secara konstruktif, individu adalah unik berbeda-beda ada kelebihan dan ada kekurangan.

Keberadaan guru pembimbing atau konselor di Sekolah Dasar masih sangat terbatas sehingga guru kelas selain mengajar juga melaksanakan bimbingan terhadap seluruh peserta didik yang menjadi tanggung jawab, karena guru kelaslah yang merupakan pembimbing dan pengasuh utama setiap hari berada bersama anak dalam proses pendidikan dasar yang amat vital dalam keseluruhan perkembangan anak. Berkat hubungan kesehariannya itu diharapkan guru memahami secara mendalam pribadi anak dalam berbagai aspek perkembangannya, hambatan dan permasalahan yang dialaminya. Sebagaimana yang tercantum di dalam Surat Keputusan Bersama Mentri Pendidikan dan Kebudayaan No. 35 tahun 1993, bahwa "disekolah dasar dan taman kanak-kanak yang belum memiliki guru pembimbing, maka kegiatan bimbingan diselenggarakan oleh guru kelas terhadap murid-murid yang menjadi tanggung jawab.

Salah satu masalah perkembangan anak yang harus diketahui oleh guru dengan baik adalah masalah hiperaktif atau yang sering disebut hiperaktivitas. Hiperaktif memang identik dengan banyaknya gerakan dan cara berfikirnya pun berbeda dengan anak yang normal, anak yang normal akan cenderung menurut dengan kontrol orang lain yang sesuai dengan hatinya sedangkan anak hiperaktif selalu "semau saya" tanpa dapat di kontrol sama sekali. ${ }^{2}$ Anak yang hiperaktif cenderung bergerak dan tak mau diam.

Kehidupan sehari-hari seorang anak sering menghadapi masalah-masalah dalam rangka beradaptasi dengan lingkungannya. Berbagai masalah timbul karena kurangnya kesalarasan perkembangan anak, yang menyangkut faktor: (1) sosial emosional, dimana anak sukar berhubungan dnegan orang lain, belum dapat mengikuti aturan-aturan secara penuh, sering membangkang jika keinginannya tidak dituruti, sulit untuk memusatkan perhatian bahkan dapat menunjukkan perilaku hiperaktif, kesulitan dalam menangkap apa yang diterima oleh pengamatan indranya, (2) kesulitan dalama bahasa, (3) perkembangan motorik kasar dan motorik halus, (4) kognitif dan (5) gangguan fisik. ${ }^{3}$

\footnotetext{
${ }^{1}$ Departemen Agama Republik Indonesia, Al-Qur'an dan Terjemah, (Jakarta: CV. Tohapura Semarang, 1989), 413

${ }^{2}$ Via Azmir, A, Gift: Anak Hiperaktif (Yogyakarta: Rapha Publishing, 2015), 6-7

${ }^{3}$ Depdiknas, Acuan Menu Pembelajaran Pada Taman Penitipan Anak, (Jakarta : Direktorat Pendidikan Anak Usia Dini Depdiknas, 2002), 12
} 
Anak hiperaktif mulai terjadi pada usia sekitar 3 tahun atau 4 tahun, sedangkan hendaknya adanya kurang pemusatan perhatian (inattention), suka menurutkan kata hati dan suka menganngu temannya (impulsivity), sikap tidak mau diam dan selalu aktif melakukan kegiatan tanpa ada penyelesaiannya. (hyperactivity), serta gejala-gejalanya mulai terlihat secara jelas pada saat yang bersangkutan masuk sekolah. Namun sebelumnya, pada orang tua yang mempunyai anak hiperaktif telah melihat adanya gejala-gejala kelainan. Gejalagejala kelainan pada anak hiperaktif, misalnya perilaku yang sangat aktif dirumah berupa perilaku suka bermain dengan melempar, membongkar barang-barang yang ada disekeliling ruangan tanpa ada penyelesaian untuk dirapikan kembali, sikap suka mengganggu dan nakal, selalu menentang, serta sangat lambat untuk memahami arahan atau latihan-latihan berkaitan dengan aktivitas sehari-hari.

Gejala-gejala kelainan hiperaktif sangat berpengaruh terhadap kehidupan sehari-hari pada anak hiperaktif sehingga yang bersangkutan mempunyai hambatan pada kemampuan fungsi kehidupannya dalam berbagai segi. Dampak berikutnya adalah dimungkinkan ia mempunyai kemampuan rendah dalam hal prestasi akademik: berfungsian ke penyesuaian diri, hubungan sosial; serta mempunyai kelainan dalam hal tidur, makan, dan memelihara kesehatan diri. ${ }^{4}$

Anak yang mengalami gangguan hiperaktif tentu akan menjadi pusat perhatian jika bergabung dengan anak normal lainnya karena akan cenderung lebih bergerak bahkan terkadang anak tersebut menyela-nyela atau menganggu teman lainnya. Dengan adanya permasalahan tersebut tentu perlu adanya metode penanganan yang tepat untuk menghadapi atau menangani anak yang mengalami hiperaktif.

Anak hiperaktif adalah anak yang mengalami gangguan pemusatan perhatian dengan hiperaktivitas atau Attention Deficit And Hyperaktivity Disorder (ADHD). Kondisi ini juga disebut sebagai gangguan hiperkinetik. Dahulu kondisi ini sering disebut minimal brain dysfunction syndrome. Terhadap kondisi peserta didik yang demikian, biasannya para guru sangat susah mengatur dan mendidiknya. Disamping karena keadaan dirinya yang sangat sulit untuk tenang, juga karena anak hiperaktif sering menganggu orang lain, suka memotong pembicaraan guru atau teman, dan mengalami kesulitan dalam memahami sesuatu yang diajarkan guru kepadannya. Selain itu juga, prestasi belajar anak hiperaktif juga tidak bisa maksimal. ${ }^{5}$ Untuk itulah dibutuhkan suatu pendekatan untuk membantu anak-anak yang hiperaktif tersebut supaya mereka dapat memaksimalkan potensi diri dan meningkatkan prestasinya.

Ditinjau secara psikologis, hiperaktif adalah gangguan tingkah laku yang tidak normal yang disebabkan disfungsi neurologia dengan gejala utama tidak mampu memusatkan perhatian. Begitu pula anak hiperaktif adalah anak yang mengalami gangguan pemusatan perhatian. Gangguan ini disebabkan kerusakan

\footnotetext{
${ }^{4}$ Bandi delphie, Layanan Perilaku Anak Hiperaktif (Sleman: PT Intan Sejati Klaten, 2009) $14-15$

${ }^{5}$ Zeviere Ferdinand, Anak Hiperaktif, Cara Cerdas Menghadapi Anak hiperaktif dan Gangguan Konsentrasi, (Jogyakarta: Katahati, 2008), 123
} 
kecil pada sistem saraf pusat dan otak sehingga rentang konsentrasi penderita menjadi sangat pendek dan sulit dikendalikan. Penyebab lainnya dikarenakan temperamen bawaan, pengaruh lingkungan, malfungsi otak, trauma kepala karena persalinan sulit atau pernah terbentur, infeksi, keracunan, gizi buruk, dan alergi makanan.

Pendekatan ini yaitu denagn adanya bimbingan konseling berupa layanan/treatment yang sesuai dengan kebutuhannya. Sehingga dengan demikian, diharapkan setiap anak akan memperoleh haknya untuk mendapatkan pendidikan yang terbaik tanpa terkecuali, karena pengajaran yang diberikan telah disesuaikan dengan kemampuan dan kesulitan yang dimilikinnya. Pengelolaan program bimbingan oleh guru dalam kegiatan belajar belum menunjukkan keoptimalan terutama dalam menangani anak yang bermasalah, pemahaman guru mengidentifikasi peserta didik yang bermaslaah belum maksimal, sehingga merekomendasikan kepada guru untuk melaksanakan layanan bimbingan terintegrasi dengan kegiatan pembelajaran.

Berdasarkan survei awal yang dilakukan peneliti di SDN Inpres Bumi Bahari, diperoleh bahwa ada 6 (enam) peserta didik yang cenderung berperilaku hiperaktif. Kedua anak tersebut memiliki karakteristik dan perilaku yang tidak sama tetapi secara umum keduanya menunjukkan sikap tidak bisa duduk tenang, berjalan kesana kemari tanpa tujuan yang jelas, sulit diatur dan sering mengganggu temannya.

Berdasarkan uraian diatas, maka penulis tertarik untuk mengkaji lebih jauh mengenai perilaku hiperaktif peserta didik dan penanganannya yang dilakukan oleh guru di SDN Inpres Bumi Bahari. Sehingga ditegaskan dalam satu judul "perilaku hiperaktif peserta didik dan penanganannya, (studi kasus di SDN Inpres Bumi Bahari).

\section{METODE PENELITIAN}

Penelitian ini penulis mengunakan pendekatan Kualitatif, sebagai mana yang di jelaskan oleh Matthew B. Miles dan A. Michel Huberman ia mengatakan: singkatnya hal-hal apa yang terdapat dalam analisis Kualitatif, Pertama, kata yang muncul berwujud kata kata dan bukan rangkaian angka. Dan itu mungkin telah di kumpulkan dalam berbagai aneka macam cara (observasi, wawancara, intisari dokumen, pita perekam,) dan yang biasanya di proses"kira kira sebelum siap di gunakan (melalui pencatatan, pengetikan, penyuntingan atau ahli tulis). Tetapi analisis kualitatif tetap di gunakan kata kata yang biasanya di susun dalam tes yang perluas. $^{6}$

Digunakan pendekatan Kualitatif dalam hal ini karena fokus pada penelitian ini bersifat mendekskripsikan perilaku hiperaktif peserta didik dan penanganannya (studi kasus di SDN Inpres Bumi Bahari). Tentunya di dalam melakukan penelitian secara kualitatif, penulis langsung memperoleh data-data yang bersumber lansung dari lokasi penelitian baik itu kepala sekolah, dewan

\footnotetext{
${ }^{6}$ Matthew B. Milles,Analisis Data Kualitatif, Buku Tentang Metode-Metode Baru (Cet.1:Jakarta,1992),.15-16
} 
guru, staf, peserta didik sebagai sumber utama dalam pengambilan data sesuai dengan penelitian ini nantinya. Jelasnya penelitian secara kualitatif bertujuan agar penelitian benar benar memperoleh data-data yang valid, sehingga dapat mempertahankan kebenaran serta keabsahan dari hasil penelitian untuk di gunakan dalam membahas selanjutnya.

Lokasi penelitian ini adalah di SDN Inpres Bumi Bahari. Dengan alasan bahwa adanya sebagian anak tidak konsentrasi dalam proses belajar mengajar, yang selalu menganggu teman ketika belajar berlangsung, dan selalu melanggar ketika disuruh diam.

Karena penelitian ini bersifat kualitatif, maka kehadiran peneliti dilapangan mutlak adanya sebagai instrumen penelitian sekaliigus sebagai pengumpul data. Peran peneliti dilapangan sebagai partisipasi penuh dan aktif karena peneliti yang langsung mengamati dan mencari informasi melalui informasi. Hal ini S. Margono mengemukakan kehadiran peneliti dilokasi penelitian selaku instrumen utama penelitian. Secara umum kehadiran peneliti diketahui oleh objek penelitian dengan tujuan untuk mendapatkan data yang valid dan akurat dari lokasi penelitian, yang berhubungan dengan fokus penelitian dari skripsi ini. Dalam penelitian ini penulis akan melakukan pengamatan atau observasi langsung dilokasi penelitian.

Dalam penelitian ini penulis membagi sumber data ke dalam dua jenis yaitu Data primer dan Data sekunder. Adapun yang menjadi sumber data dalam penelitian ini adalah tenaga pendidik sebanyak 4 orang. Sedangkan anak yang berperilaku hiperaktif peneliti mengambil 6 (enam) orang anak sebagai berkasus.

Adapun teknik pengumpulan data yang digunakan dalam penelitian ini adalah: (1) Observasi, (2) Wawancara atau interviu dan (3) Dokumentasi. Dalam teknik pengumpulan data ini peneliti melakukan penelitian dengan menghimpun data relevan dari sejumlah dokumen resmi atau arsip penting yang dapat menunjang kelengkapan dan penelitian, serta dalam teknik dokumentasi ini, penulis juga menggunakan tape recorder sebagai transkip wawancara dan kamera sebagai bukti bahwa penelitian benar-benar di lakukan lokasi yang dimaksud.

Teknik analisis data yang digunakan pada penelitian ini adalah data secara kualitatif. Setelah pengumpulan data yang dilaksanakan maka selanjutnya Penulis melakukan analisis data sebagai berikut (1)Reduksi Data, (2) Penyajian data dan (3) Verifikasi Data.

\section{HASIL PENELITIAN}

Mendidik anak untuk bisa pintar mungkin bisa dilakukan oleh siapa saja. Tetapi mendidik anak untuk mempunyai emosi yang stabil, tidak semua orang bisa melakukannya. Dibutuhkan orang tua dan guru yang sabar, serius, ulet, serta mempunyai semangat yang tinggi dalam memahami dinamika kepribadian anak. Perilaku peserta didik usia sekolah saat ini beragam, salah satu perilakunnya yaitu peserta didik yang sangat sulit untuk diatur, tidak bisa diam dan seolah-olah tidak memperhatikan pelajaran di kelas. Peserta didik tersebut biasanya mengalami gangguan dalam perkembangannya yaitu gangguan hiperkinetik yang secara luas di masyarakat disebut sebagai anak hiperaktif. 
Penulis melakukan observasi secara langsung di dalam kelas II B pada awalnya untuk mengamati proses pembelajaran di dalam kelas. Pertama kali penulis masuk di dalam kelas. Penulis melihat ada seorang anak laki-laki yang terlihat bermain-main pada saat pelajaran berlangsung. Anak tersebut bernama Fayat, tidak hanya Fayat tetapi ada juga peserta didik yang lain yang terlihat susah untuk diam dan sulit untuk berkonsentrasi mengikuti pembelajaran yang sedang berlangsung. Setelah penulis mencari tahu, ternyata anak tersebut bernama Ahmad. Saat Fayat ramai di dalam kelas, guru mencoba untuk menegurnya dan pada akhirnya Fayat terlihat lebih tenang untuk beberapa menit saja. Selain itu ahmad juga terlihat sering keluar masuk kelas tanpa alasan yang jelas, sehingga guru mencoba mengunci pintu dari dalam agar ahmad tidak bisa keluar masuk kelas lagi. ${ }^{7}$

Setelah melihat perilaku Fayat dan Ahmad penulis melakukan wawancara dengan guru kelas. Guru tersebut mengungkapkan bahwa di dalam kelas II B ada beberapa peserta didik yang tidak bisa diam diantaranya yang paling parah adalah fayat dan ahmad.

Beliau berkata bahwa Fayat dan Ahmad adalah peserta didik yang paling hiperaaktif di dalam kelas, (1) susah diajak berkonsentrasi, (2) sulit memusatkan perhatian, (3) keluar masuk kelas, (4) suka usil, dan (5) terlalu banyak gerak. Fayat paling suka menganggu temannya di dalam kelas, tetapi fayat sendiri tipe yang tidak mau diganggu. Sedangkan ahmad tidak bisa diam ketika diberi tugas oleh gurunya, selalu menggerak gerakkan kakinya pada saat sedang duduk. ${ }^{8}$

Berdasarkan hasil observasi dan wawancara di atas, maka penulis dapat memahami bahwa perilaku peserta didik hiperaktif ketika berada di dalam kelas sering keluar masuk pada saat proses pembelajaran sedang berlangsung, dan sulit diam pada waktu yang lama. Sering menganggu temannya yang sedang fokus dalam pembelajaran.

Penulis juga melakukan wawancara dengan salah satu teman sekelas fayat dan ahmad, yaitu:

"Fayat dan Ahmad sering menganggu saya kalau saya lagi belajar dan dia juga sering mengambil barang punya saya apalagi pulpen ku dia sering ambil padahal dia juga punya pulpen sendiri, tapi Fayat dan ahmad orangnya baik."

Perilaku yang ditunjukan oleh peserta didik dalam proses pembelajaran berbeda-beda, ada yang pendiam dan ada yang hiperaktif, tergantung dari faktor yang mempengaruhi dan di mana peserta didik bergaul. Adapun perilaku peserta didik yang hiperaktif di SDN Inpres Bumi Bahari. Sebagaimana yang diungkapkan oleh salah satu guru di SDN Inpres Bumi Bahari yaitu:

"peserta didik yang berperilaku hiperaktif sangat sulit untuk diatur, tidak dapat duduk diam di dalam kelas, perhatian mudah teralihkan dan sangat

\footnotetext{
${ }^{7}$ Hasil Observasi tanggal 17 juli 2019

${ }^{8}$ Lilis, Guru kelas di SDN Inpres Bumi Bahari, “Wawancara”, Dalam kelas, tanggal 17 juli 2019
} 
sulit berkonsentrasi, dan tidak bisa diam dalam waktu yang lama. Berbagai perillaku yang dimiliki peseta didik betul-betul melatih kesabaran guru pada saat proses pembelajaran. ${ }^{9}$

Berdasarkan uraian di atas, bahwa perilaku peserta didik yang berperilaku hiperaktif sangat sullit diatur dan tidak bisa diam dalam waktu yang lama dan tidak bisa memusatkan perhatainnya dengan baik. Sering bergerak kesana kemari tanpa tujuan yang jelas, mengalami kesulitan dalam meyelesaikan tugas. selain itu peserta didik kurang konsentrasi dalam belajar sehingga kurang perhatian di dalam kelas sehingga menimbulkan prestasi belajarnya kurang.

Konsentrasi yang mudah terganggu akan membuat peserta didik tidak dapat menyerap materi pelajaran secara keseluruhan dan tidak dapat memusatkan perhatiannya sehingga membuat peserta didik ingin cepat selesai tugasnya bila ada tugas yang diberikan oleh guru.

"Peserta didik hiperaktif mengalami kesulitan membaca dan menulis. Sehingga menyulitkan guru dalam proses pembelajaran apalagi ketika peserta didik yang hiperaktif tidak memiliki perhatian yang lebih serius dan sering menganggu temannya yang lainnya. Dan kalau ada tugas rumah yang diberikan oleh guru sering lupa untuk dikerjakan". ${ }^{10}$

Sebagaimana yang diungkapakan oleh peserta didik bahwa:

"kalau ada tugas rumah yang diberikan oleh guru kadang saya lupa mengerjakannya karena saya keasikan bermain sehingga saya lupa kalau ada

PR dan saya juga tidak mengerti bagaimana cara mengerjakanannya". ${ }^{11}$

Dapat dipahami bahwa peserta didik yang hiperaktif tidak memiliki perhatian yang serius ketika sedang proses pembelajaran sehingga apabila ada PR yang diberikan oleh guru peserta didik tersebut kesulitan dalam mengerjakannya karena kurangnya perhatian ketika guru menjelaskan pelajaran tersebut.

Dalam proses pembelajaran seorang guru dibutuhkan kesabaran dan keikhlasan untuk membimbing para peserta didik dengan karakter yang berbedabeda. Ketidak mampuan guru menghadapi perilaku peserta didik yang hiperaktif seperti yang ada di SDN Inpres Bumi Bahari, akan menyulitkan untuk mencapai tujuan pembelajaran yang maksimal. Oleh karena itu, dengan beragam perilaku hiperaktif yang muncul dari peserta didik dibutuhkan strategi agar guru dapat mengarahkan peserta didik tersebut. Diantaranya dijelaskan oleh guru wali kelas di bawah ini

Hasil wawancara peneliti dengan guru wali kelas mengenai tentang strategi yang dilakukan terhadap peserta didik yang hiperaktif adalah sebagai berikut:

${ }^{9}$ Nengah Sutiasa, Guru Kelas di SDN Inpres Bumi Bahari, “Wawancara”, Ruang Guru, tanggal 17 juli 2019 21 juli 2019

${ }^{10}$ Lilis, Guru kelas di SDN Inpres Bumi Bahari, “Wawancara”, Dalam kelas, tanggal 21 Juli 2019

${ }^{11}$ Dimas, siswa kelas II SDN Inpres Bumi Bahari, “Wawancara” Dalam kelas tanggal 
"Beliau mengatakan bahwa strategi yang dilakukan terhadap peserta didik yang hiperaktif yaitu dengan memberikan sentuhan dengan kata lembut dan mengusap kepalanya agar peserta didik tersebut patuh dengan kata-kata guru, menunjukkan sikap tegas tetapi tidak perlu marah, karena dengan sikap tegas berharap peserta didik tidak membangkang ketika proses pembelajaran berlangsung, tetapi tidak perlu marah, berikan perlakuan sama seperti peserta didik yang lain agar peserta didik tersebut tidak merasa dibeda-bedakan, berika semangat dengan yel-yel agar peserta didik tidak merasa jenuh selama proses pembelajaran berlangsung". ${ }^{2}$

Berdasarkan hasil wawancara di atas dapat dipahami bahwa strategi yang dilakukan oleh guru cukup baik, dikarenakan strategi yang dilakukan oleh guru membuat peserta didik merasa nyaman dan tidak merasa jenuh pada saat mengikuti proses pembelajaran sehingga peserta didik yang tadinya sulit diatur menjadi tenang selama pembelajaran berlangsung.

Selain itu, peserta didik yang hiperaktif tidak berlaku di siplin sehingga guru kesulitan memberikan nasehat karena nasehatpun kadang tidak didengar dan di patuhi. Hal ini sebagaimana disampaikan oleh salah satu guru di SDN Inpres bumi Bahari bahwa :

"Peserta didik hiperaktif walaupun sudah ditegur secara berulang-ulang, tetap masih saja mengulangi kesalahannya, misalkan : datang terlambat ke sekolah, berjalan kesana kemari pada saat proses pembelajaran berlamgsung, dan tidak membawa perlengkapan belajarnya. Sehingga itu semua akan menghambat proses pembelajaran dan bahkan menganggu konsentrasi teman lainnya". ${ }^{13}$

Hal ini sesuai dengan ungkapan peserta didik sebagai berikut :

"saya datang terlambat ke sekolah karena semalam saya main games dan menonton TV sampai larut malam, sehingga saya bangunnya kesiangan dan saya terburu-buru ke sekolah akhirnya saya lupa membawa polpen tidak sempat lagi periksa perlengkapan sekolah". ${ }^{14}$

Berdasarkan hasil wawancara diatas, dapat dipahami bahwa pada dasarnya peserta didik yang berperilaku hiperaktif yang ada di SDN Inpres Bumi Bahari sulit dikendalikan oleh guru, karena walaupun guru sering menasehati dan ditegur tetapi masih saja peserta didik melakukan pelanggaran-pelanggaran.

Perkembangan anak pada dasarnya tidak dapat dipisahkan dari lingkungan anak tersebut tumbuh dan berkembang. Keluarga merupakan lingkungan pertama dan yang paling utama bagi seorang anak, kemudian lingkungan diluar rumah, tetangga teman-teman, dan guru bila anak sudah bersekolah. Lingkungan sekolah merupakan lingkungan kedua setelah lingkungan keluarga yang akan memberiakn situasi untuk pertumbuhan dan perkembangan anak. Sebaliknya, lingkungan sekolah juga dapat

\footnotetext{
21 juli 2019

${ }^{12}$ Lilis, Guru kelas di SDN Inpres Bumi Bahari, "Wawancara”, Dalam kelas, tanggal

${ }^{13}$ Nengah Sutiasa, Dalam kantor, “Wawancara” pada tanggal 21 juli 2019

${ }^{14}$ Chiko, siswa kelas IV SDN Inpres Bumi Bahari, “Wawancara” Dalam kelas tanggal 
menjadi penghambat bila tidak dapat melayani perbedaan-perbedaan individual tentang kebutuhan anak.

Dengan beragam perilaku yang menyimpang dari perilaku hiperaktif diharapkan guru dapat mengenali gejala-gejala perilaku yang telah ditunjukan oleh peserta didik yang ada di SDN Inpres Bumi Bahari agar peserta didik mendapatkan penanganan yang tepat dan dapat belajar lebih normal dan dapat memperoleh hasil belajar yang lebih maksimal.

\section{PEMBAHASAN}

Terhadap kondisi peserta didik yang berperilaku hiperaktif, biasanya para guru sangat susah mengatur dan mendidiknya. Disamping karena keadaan dirinya yang sangat sulit untuk tenang, juga karena peserta didik hiperaktif sering menganggu orang lain, suka memotong pembicaraan guru atau temannya, dan menggalami kesulitan dalam memahami sesuatu yang diajarkan oleh guru kepadanya. Untuk itu dibutuhkan suatu penanganan untuk membantu peserta didik yang berperilaku hiperaktif tersebut supaya mereka dapat memaksimalkan potensi diri dan meningkatkan prestasinnya. Sehingga dengan adanya penanganan diharapkan setiap peserta didik akan memperoleh haknya untuk mendapatkan pendidikan yang terbaik tanpa terkecuali.

Adapun upaya yang dilakukan oleh pihak sekolah untuk menangani peserta didik yang berperilaku hiperaktif sebagaimana yang diungkapkan oleh informan yaitu sebagai berikut:

Dalam mengatasi perilaku peserta didik hiperaktif seorang guru melakukan tehnik-tehnik dalam pengelolaan perilaku, seperti menerapkan aturan secara perlahan kepada peserta didik (misalnya: menyuruh peserta didik agar tidak berkeliaran di dalam kelas), membantu peserta didik dalam pembelajaran (misalnya: menanyakan kepada peserta didik jika ada yang belum di pahami), menggunakan penguatan positif (misalnya: memberikan pujian kepada peserta didik yang berpakaian rapi, bersih, dan sopan). Memberi perlakuan yang sama dengan teman lainnya, memberi peringatan teman satu kelasnya untuk tidak antipasi terhadapnya. Bahkan mereka bisa berperan membantu peserta didik hiperaktif agar bisa normal kembali. Mendorong untuk aktif olahraga tidak hanya saat pelajaran di sekolah namun juga dirumah, karena olahraga merupakan aktivitas yang membutuhkan energi, sehingga peserta didik tersebut menyadarinya ia akan tahu aktivitas apa yang bisa mengalihkannya dari rasa frustasi dan marah berlebihan. ${ }^{15}$

Dan di tambahkan oleh salah satu guru i SDN Inpres Bumi Bahari yaitu sebagai berikut :

Guru bisamemberikan terapi bermain kepada peserta didik yang hiperaktif (misalnya : tepuk tangan, merentangkan tangan menyusun balok, dan alat bermain yang lain), dengan mengenalkan gerakan yang lain dan bermain yang dapat digunakan maka diharapkan dapat digunakan untuk mengalihkan

${ }^{15}$ Lilis, Guru kelas di SDN Inpres Bumi Bahari, “Wawancara”, Dalam kelas, tanggal 22 juli 2019 
agresivitas muncul, juga jika anak yang sering berlarian tk bertujuan atau tidak bisa diam di dalam kelas. ${ }^{16}$

Berasarkan hasil wawancara diatas, maka dapat dipahami bahwa pada usia SD sangatlah membutuhkan sanjungan dan pujian agar peserta didik merasa tambah percaya diri dan lebih bersemangat lagi belajar. Serta memberikan penghargaan aats apa yang dilakukan dalam segala aktivitasnya agar peserta diik merasa berguna terhadap hasil karyanya sehingga akan semakin semangat dalam belajarnya.

Penulis melakukan observasi secara langsung didalam kelas pada saat proses belajar mengajar berlangsung. Penulis memperhatikan apa saja upaya guru dalam penanganan peserta didik yang berperilaku hiperaktif, uapaya yang dilakukan oleh guru adalah dengan menerapkan aturan kepada peserta didik seperti, menyuru peserta didik agar tidak berkeliaran didalam kelas. Membantu peserta didik dalam pembelajaran, memberikan pujian kepada peserta didik yang berpakaian rapi, bersih dan sopan. ${ }^{17}$

Guru merupakan salah satu penunjang dalam meningkatkan hasil belajar peserta didik. Oleh karena itu, seorang guru harus mengetahui karakter dan kemampuan yang dimiliki oleh setiap peserta didiknya, agar peserta didik merasa puas ketika dalam proses pembelajaran dan peserta didik dapat memperoleh hasil belajar yang maksimal sesuai dengan harapan. Salah satu upaya yang dilakukan oleh guru yang ada di SDN Inpres Bumi Bahari dalam penanganan peserta didik yang hiperaktif yaitu sebagai berikut :

menempatkan posisi duduk peserta didik yang hiperaktif paling depan, agar peserta didik bisa fokus ke pembelajaran selain itu juga guru akan lebih mudah untuk menjangkau peserta didik hiperaktif tersebut. Dengan memposisikan tempat duduk paling depan mereka akan lebih berhati-hati dalam bertingkah di dalam kelas. Tidak memberikan hukuman yang terlalu berat, dengan adanya diberikan hukuman peserta didik yang hiperaktif akan merasa lebih bertanggung jawab atas apa yang ia lakukan. Hal ini bertujuan agar lebih bersemangat dalam proses pembelajaran. ${ }^{18}$

Dalam proses pembelajaran guru juga harus mengenali kelebihan dan bakat peserta didik, agar kelebihan dan kemampuan yang di miliki oleh peseta didik dapat tersalurkan dengan baik, dan peserta didik juga dapat mengembangka bakat yang mereka miliki masing-masing sesuai dengan kemampuannya. Kelebihan dan bakat yang di miliki oleh setiap peserta didik merupakan hal yang sangat penting di kembangkan, agar peserta didik dapat menikmati aktivitasnya sesuai dengan kemampuannya masing-masing, selaku guru harus mngarahkan dan membimbing peserta didiknya agar dapat tumbuh dan berkembang secara normal.

Dalam proses pembelajaran peserta didik yang berperilaku hiperaktif memiliki kesulitan dalam menyelesaikan tugas sekolah, dan tugas seorang guru adalah membantu peserta didik yang kesulitan menyelesaikan tugasnya. Hal ini sebagaimana di ungkapkan oleh guru di SDN Inpres Bumi Bahari sebagai berikut:

\footnotetext{
${ }^{16}$ Hasil Observasi tanggal 22 juli 2019

${ }^{17}$ Hasil Observasi tanggal 22 juli 2019

${ }^{18}$ Lilis, Guru kelas di SDN Inpres Bumi Bahari, “Wawancara”, Dalam kelas, tanggal
} 22 juli 2019 
Peserta didik yang hiperaktif memiliki kendala dalam menyelesaikan tugasnya karena memang mereka tidak terlalu memperhatikan pada saat guru sedang menjelaskan dan sulit berkonsentrasi terhadap apa yang di sampaikan oleh gurunya. Sehingga apabila ada tugas yang diberikan oleh guru mereka sering memiliki alasan tidak mengerjakan tugasnya karena lupa, perilaku yang seperti ini guru dapat mengatasinnya dengan mendampinginnya dalam menyelesaikan tugasnya. ${ }^{19}$

Tugas guru memang sangat berat, bukan hanya menyampaikan materi begitu saja kepada peserta didiknya , namun bagaimana caranya agar peserta didik dapat menguasai dan paham serta dapat mengimplementasikan materi yang diajarkan oleh guru dalam kehidupan sehari-hari.

Pembelajaran juga akan lebih mudah dipahami oleh peserta didik apabila didukung oleh media dan metode yang menarik. Karena kedudukan metode dan media dalam pembelajaran merupakan hal yang sangat penting dan dapat lebih memudahkan peserta didik dalam belajarnya. Oleh karena itu metode dan media yang di gunakan haruslah tepat, sebagaimana yang diungkapkan oleh guru di SDN Inpres Bumi Bahari yaitu sebagai berikut :

Untuk mengatasi perilaku peserta didik yaitu dengan melalui penerapan metode dan media yang tepat dan dapat merangsang motivasi peserta didik untuk belajar, melalui media yang menarik dapat merangsang peserta didik untuk berfikir dan beraktivitas secara aktif dalam proses pembelajaran, sehingga pembelajaran dapat berpusat pada peserta didik. ${ }^{20}$

Sesuai dengan pengamatan yang penulis lakukan uapaya yang dilakukan oleh guru yaitu dengan menempatkan posisi tempat duduk peserta didik yang hiperaktif paling depan agar peserta didik tersebut lebih fokus dalam pembelajaran sealain itu juga guru akan lebih mudah untuk menjangkau peserta didik hiperaktif tersebut. ${ }^{21}$

Dari 6 peserta didik yang hiperaktif di SDN Inpres Bumi Bahari 2 dari mereka yang paling menonjol, dan perilaku yang mereka tunjukkan tentu sangat berpengaruh terhadap prestasi belajarnya karena perhatian mereka terhadap pelajaran juga kurang, dan mereka sering lupa mengerjakan tugas-tugasnya yang diberikan oeh guru bahkan sering menganggu teman-temannya yang lain di dalam kelas. Namun, dengan perilaku yang mereka miliki guru tetap berusaha agar peserta didik tersebut dapat berubah dan dapat memiliki perhatian yang serius dalam proses pembelajaran. Dengan cara seperti itu, peserta didik mendapatkan langsung pengalaman dari proses pembelajaran, pembelajaran menjadi berpusat pada peserta didik karena diberikan kebebasan untuk berkreasi dan berfikir sesuai dengan hasil pemahamannya masingmasing.

\footnotetext{
${ }^{19}$ Nengah Sutiasa, Guru Kelas, “Wawancara” pada tanggal 22 juli 2019

${ }^{20}$ Lilis, Guru kelas di SDN Inpres Bumi Bahari, "Wawancara”, Dalam kelas, tanggal
} 


\section{KESIMPULAN}

Berdasarkan berbagai uraian yang telah dikemukakan dalam bab-bab sebelumnya, maka dapat disimpulkan bahwa Perilaku peserta didik hiperaktif di SDN Inpres Bumi Bahari yaitu tidak dapat duduk tenang di dalam kelas dan tampak gelisa dan tidak mampu memusatkan perhatiannya secara terus menerus. Ketika ditegur oleh guru tidak mendengar apa yang guru katakan, tugas rumah sering lupa untuk dikerjakan, dan terkadang lupa membawa perlengkapan tulis ke sekolah, dan sangat sulit untuk berfikir yang memerlukan konsentrasi serta sering menganggu teman lainnya pada saat proses pembelajaran. Perilaku peserta didik hiperaktif dapat menganggu situasi dan kondisi pembelajaran.

Upaya-upaya yang dilakukan dalam penanganan perilaku peserta didik hiperaktif seorang guru adalah menerapkan aturan secara perlahan kepada peserta didik, membantu peserta didik dalam pembelajaran, menggunakan penguatan positif. Memberi perlakuan yang sama dengan teman lainnya, memberi peringatan teman satu kelasnya untuk tidak antipasi terhadapnya, menempatkan posisi duduk peserta didik yang hiperaktif paling depan, Tidak memberikan hukuman yang terlalu berat, dengan adanya diberikan hukuman peserta didik yang hiperaktif akan merasa lebih bertanggung jawab atas apa yang ia lakukan. Memotivasi agar lebih bersemangat dalam proses pembelajaran.

\section{SARAN}

Guru hendaknya lebih memahami kepribadian dan karakter peserta didik, dan memberikan perlakuan yang tepat sehingga pembelajaran berjalan dengan lancar dan hasil yang dicapai pun sesuai dengan yang diharapkan. Guru juga harus lebih kreatif dalam mengelolah proses pembelajaran agar peserta didik dapat berkonsentrasi dengan baik pada saat proses pembelajaran berlangsung.

\section{DAFTAR PUSTAKA}

Bandi delphie, Layanan Perilaku Anak Hiperaktif Sleman: PT Intan Sejati Klaten, 2009

Chiko, siswa kelas IV SDN Inpres Bumi Bahari, "Wawancara” Dalam kelas tanggal 21 Juli 2019

Departemen Agama Republik Indonesia, Al-Qur'an dan Terjemah, Jakarta: CV. Tohapura Semarang, 1989

Depdiknas, Acuan Menu Pembelajaran Pada Taman Penitipan Anak, Jakarta : Direktorat Pendidikan Anak Usia Dini Depdiknas, 2002

Dimas, siswa kelas II SDN Inpres Bumi Bahari, "Wawancara” Dalam kelas tanggal 21 Juli 2019

Hasil Observasi tanggal 17 juli 2019

Lilis, Guru kelas di SDN Inpres Bumi Bahari, "Wawancara” , Dalam kelas, tanggal 21 juli 2019 
Matthew B, Milles, Et Al, Qualitative Data Analisys Diterjemahkan Oleh Tjetjep Rohidi Dengan Judul Analisis Data Kualitatif; Buku Sumber Tentang Metode Baru, Cet, I; Jakarta: UI-Press, 1992

Nengah Sutiasa, Dalam kantor, "Wawancara” pada tanggal 22 juli 2019

Via Azmira, A, Gift: Anak Hiperaktif Yogyakarta: Rapha Publishing, 2015

Zeviere Ferdinand, Anak Hiperaktif, Cara Cerdas Menghadapi Anak hiperaktif dan Gangguan Konsentrasi, Jogyakarta: Katahati, 2008 